University of Nebraska - Lincoln

DigitalCommons@University of Nebraska - Lincoln

Faculty Publications, Department of Psychology

Psychology, Department of

2017

\title{
A Concept Analysis of Resilience Integrating Genetics
}

Kosuke Niitsu

University of Nebraska Medical Center, KosukeNiitsu@gmail.com

Julia F. Houfek

University of Nebraska Medical Center, jhoufek@unmc.edu

Cecilia R. Barron

University of Nebraska Medical Center, crbarron@cox.net

Scott F. Stoltenberg

University of Nebraska-Lincoln, sstoltenberg2@unl.edu

Kevin A. Kupzyk

University of Nebraska Medical Center, kevin.kupzyk@unmc.edu

See next page for additional authors

Follow this and additional works at: https://digitalcommons.unl.edu/psychfacpub

Part of the Genetics Commons, and the Psychology Commons

Niitsu, Kosuke; Houfek, Julia F.; Barron, Cecilia R.; Stoltenberg, Scott F.; Kupzyk, Kevin A.; and Rice, Michael J., "A Concept Analysis of Resilience Integrating Genetics" (2017). Faculty Publications, Department of Psychology. 1030.

https://digitalcommons.unl.edu/psychfacpub/1030

This Article is brought to you for free and open access by the Psychology, Department of at DigitalCommons@University of Nebraska - Lincoln. It has been accepted for inclusion in Faculty Publications, Department of Psychology by an authorized administrator of DigitalCommons@University of Nebraska - Lincoln. 


\section{Authors}

Kosuke Niitsu, Julia F. Houfek, Cecilia R. Barron, Scott F. Stoltenberg, Kevin A. Kupzyk, and Michael J. Rice 

.1350225

Copyright (C) 2017 Taylor \& Francis. Used by permission.

Published online August 2, 2017.

\title{
A Concept Analysis of Resilience Integrating Genetics
}

\author{
Kosuke Niitsu, MSN, APRN-NP, PMHNP-BC, ${ }^{1}$ Julia F. Houfek, PHD, APRN-CNS, ${ }^{1}$ \\ Cecilia R. Barron, PHD, RN, ${ }^{1}$ Scott F. Stoltenberg, $\mathrm{PHD},{ }^{2}$ \\ Kevin A. Kupzyk, PHD, ${ }^{1}$ and Michael J. Rice, PHD, APRN, FAAN ${ }^{3}$
}

1. College of Nursing, University of Nebraska Medical Center, Omaha, Nebraska, USA

2. Department of Psychology, University of Nebraska-Lincoln, Lincoln, Nebraska, USA

3. College of Nursing, University of Colorado Anschutz Medical Campus, Aurora, Colorado, USA

Corresponding author - Kosuke Niitsu, email kosuke.niitsu@unmc.edu, ORCID http://orcid.org/0000-0001-5383-7523

\begin{abstract}
Although clinicians and researchers are interested in the phenomenon of resilience, there is no agreed-upon definition of resilience. Scientific evidence suggests that resilience is influenced by intrapersonal (e.g., personality traits) and environmental (e.g., social support) variables. A concept analysis was conducted to better understand the meaning of resilience. In this analysis, the antecedent of resilience was a potentially traumatic event; the defining attributes were ego-resiliency, emotion regulation, social support, and heredity; and the consequences were none to mild psychopathological symptoms and positive adaptation. This analysis can help nurses better understand resilience and its relationships to both intrapersonal and environmental variables.
\end{abstract}

\section{Introduction}

Resilience has been of increasing interest among both clinicians and researchers. However, there is no single agreed-upon definition of resilience in the clinical or scientific literature (Fletcher \& Sarkar, 2013; Southwick \& Charney, 2012b; Southwick, Litz, Charney, \& Friedman, 2011), even among experts specializing in resilience research (Southwick, Bonanno, 
Masten, Panter-Brick, \& Yehuda, 2014). For example, it has been debated if resilience is best categorized as an individual trait, a process, an outcome, a dynamic developmental process, or all of the above (Reich, Zautra, \& Hall, 2010).

Concept analysis is the process of examining the basic elements of a concept to investigate its structure and function (Walker \& Avant, 2011). According to Walker and Avant (2011), a concept has three components: antecedents, defining attributes, and consequences. Although the analysis itself must be rigorous and precise, the end product is always tentative and may be different than other analyses of the same concept because a concept is constantly changing, influenced by cultural, contextual, and societal factors (Walker \& Avant, 2011). Several investigators have conducted a concept analysis on resilience with somewhat different results. For example, Dyer and McGuinness (1996) identified antecedents of resilience as: (1a) adversity and (1b) the presence of at least one caring, emotionally available person at some point in the person's life; defining attributes as (2a) rebounding and carrying on, $(2 \mathrm{~b})$ sense of self, $(2 \mathrm{c})$ determination, and $(2 \mathrm{~d})$ prosocial attitude; and consequences as (3a) effective coping, (3b) toughening effect, (3c) sense of having overcome one situation. In contrast, Gillespie, Chaboyer, and Wallis (2007) analyzed the antecedents of resilience as (1a) adversity, (1b) interpretation of the situation as traumatic, (1c) cognitive ability, and (1d) realistic world-view; defining attributes as (2a) self-efficacy, (2b) hope, and (2c) coping; and consequences as (3a) integration, (3b) control, (3c) adjustment, and (3d) growth. Whereas Dyer and McGuinness (1996) considered coping, for example, as a consequence of resilience, Gillespie et al. (2007) identified coping as a defining attribute.

In addition, recent advances in molecular genetics and genetic technologies enable us to investigate gene by environment interactions and the molecular mechanisms that promote resilience (Cicchetti, 2010). To our knowledge, none of the concept analyses on resilience have incorporated a genetic aspect. The purpose of this concept analysis is to better understand the broad meaning of resilience, including genetic influence on resilience.

\section{Method}

Using the Walker and Avant (2011) method, uses of the concept associated with resilience were identified first. Next, antecedents, defining attributes, and consequences of resilience were analyzed. To do so, the elements that are the most frequently associated with the concept and that allow the analyst to have the broadest insight into the concept were identified (Walker \& Avant, 2011). Finally, cases (model, related, and contrary) based on the results of the concept analysis of resilience were developed. Empirical evidence was incorporated throughout the analysis.

Search engines, including PubMed, CINAHL, and Google Scholar were utilized to search for articles addressing resilience. The following keywords were used: "resilience," "genetics," "genes," "polymorphism," "posttraumatic stress disorder (PTSD)," "trauma," and "adversity." The publication date was not restricted to review comprehensively. Approximately 500 publications were reviewed, including book chapters and peer-reviewed articles. Although animal studies are essential in behavioral genetic research (Plomin, Defries, Knopik, \& Neiderhiser, 2013), only human studies were reviewed. 


\section{Identifying uses of the concept of resilience}

One task at the initial stage of concept analysis is to identify the many uses of the concept by using resources, such as dictionaries, thesauruses, and interdisciplinary literature (Walker \&Avant, 2011). The term resilience derives from the Latin verb resilire, which means "to leap back, spring back" (Simpson, 1959, p. 517). The Oxford English Dictionary defines resilience as "the (or an) act of rebounding or spring back; rebound, recoil" (Simpson \&Weiner, 1989, p. 714). Another dictionary, theWebster's New World College Dictionary, defines resilience as "a) the ability to bounce or spring back into shape, position, etc. b) the ability to recover strength, spirits, good humor, etc." (Agnes, 2000, p. 1220). According to a thesaurus (Dictionaries, 1995), synonyms of resilience are:

1. The ability to recover quickly from depression or discouragement: bounce, buoyancy, elasticity, resiliency. 2. The quality or state of being flexible: bounce, ductility, elasticity, flexibility, flexibleness, give, malleability, malleableness, plasticity, pliability, pliableness, pliancy, pliantness, resiliency, spring, springiness, suppleness (p. 830).

Although flexibility, for example, is one of the synonyms for resilience, it is slightly different from resilience because flexibility does not necessarily require an object to return to its original shape, whereas resilience does.

In material sciences, resilience refers to the ability of certain materials, such as rubber, to withstand compression and return to their original shape or position (Denhardt \& Denhardt, 2010). In engineering, resilience is "a return time to a single, global equilibrium" (Gunderson, 2000, p. 435). In ecological systems, resilience is considered as "the amount of disturbance that a system can absorb without changing stability domains" (Gunderson, 2000, p. 435). In physics, resilience is "the energy per unit volume absorbed by a material when it is subjected to strain, or the maximum value of this when the elastic limit is not exceeded" (Simpson \& Weiner, 1989, p. 714). Resilience per cubic inch in direct tension or compression may be formulated as $f / 2 E$, where $f$ is the intensity of stress induced and $E$ is the modulus of elasticity (Almedom \& Glandon, 2007).

The concept of resilience was adapted to psychology to describe individuals who can "bounce back" when they face challenges (Denhardt \& Denhardt, 2010). Analogous to material science of resilience to explain psychological resilience, one metaphor is wrought iron that is "soft, malleable, and bends without breaking (resilient)" in contrast to cast iron that is "hard, brittle, and breaks easily (not resilient)" (Tugade \& Fredrickson, 2004, p. 320). However, the metaphor of "wrought iron" does not necessarily capture the quality of resilience to return to its original shape or state (i.e., flexibility vs. resilience).

Because one of authors $(\mathrm{KN})$ grew up in Japan, the resilience literature written in the Japanese language was also explored to describe its multicultural translatability. There is debate about how to define resilience in Japanese as well, especially because the science of resilience emerged from the Western countries (Ishihara \& Nakamaru, 2007). In Western countries, the context of adversity and the cultural background of the study participants may be quite different from Japan (Ishihara \& Nakamaru, 2007). Resilience is often 
translated into Japanese simply as "resilience" to imply that the term is imported from the West. In fact, one Japanese researcher who developed a scale to measure resilience named it "Bidimensional Resilience Scale (BRS)" (Hirano, 2010), without translating the term into Japanese. In this scale, Hirano (2010) operationalized resilience factors into two dimensions: (1) innate resilience factors that include optimism, control, sociability, and vitality, and (2) acquired resilience factors that include attempting to solve a problem, self-understanding, and understanding others. This conceptualization of resilience incorporates both trait (innate) and dynamic developmental (acquired) categories or views of resilience.

In contrast, other Japanese researchers have attempted to academically translate the word resilience into Japanese, although there is no single agreed-upon term. For example, Nishizono (2007) called resilience “Kaifuku-ryoku (回復力)." “Kaifuku (回復)” means recovery or healing, and "ryoku (力)" means ability, power, or strength. Another proposed term is “Sippei-teikou-sei (疾病抵抗性疾)" or more simply, “Kou-byou-ryoku (抗病力)," implying that the concept of resilience can occur in both health and illness: (1) the ability to withstand the onset of disease while healthy, and (2) the ability to recover, or the "restitutive" force, after becoming ill (Den, Yagi, Tanabe, \& Watanabe, 2008; Yagi, Den, \& Watanabe, 2007). More casually, the Nippon Hoso Kyokai (NHK, 2014), which is Japan's national public broadcasting organization, has released a documentary about resilience, and they coined a new Japanese term, “Gyakkyou-ryoku (逆境力)." “Gyakkyou (逆境)” means adversity or challenge, and "ryoku (力)" is the ability, power, or strength. This definition incorporates the idea that adversity is essential for resilience to occur.

Whether in theWestern countries or in Japan, the definition of resilience varies greatly. Even in the cast iron vs. wrought iron example, it is debatable if resilience is a trait (e.g., wrought iron being flexible), process (e.g., withstanding bending), or outcome (e.g., not broken). However, whether it is material science, engineering, or psychology, it appears the presence of a force (e.g., to bend the iron) or a threat is required for resilience to emerge as a phenomenon, and then an outcome follows as an evidence of resilience (e.g., not broken), influenced by characteristics (e.g., malleable) and other factors. In this sense, an antecedent must happen first, and then consequences of resilience occur influenced by attributes of resilience. Overall, resilience could refer to the dynamic process that comprehensively includes the trait, ability, process, and outcome.

\section{Identifying antecedents, defining attributes, and consequences of resilience}

\section{Antecedent of resilience}

Antecedents are events or incidents that occur prior to the manifestation of the concept (Walker \& Avant, 2011). In order for resilience as a dynamic process to occur, an event that carries substantial threat of a negative outcome must happen (Carver, 1998; Davydov, Stewart, Ritchie, \& Chaudieu, 2010; Rutten et al., 2013); such an extreme adversity is described as a potentially traumatic event (PTE) (Bonanno, 2004).

\section{Potentially traumatic event (PTE)}

Historically, the science of resilience was established by the developmental researchers who investigated children who "did well" despite exposure to risk factors such as poverty 
(Garmezy, 1993), maternal mental illness (Rutter, 1987), and perinatal complications (Werner, 1994). The concept of resilience has evolved (Tusaie \& Dyer, 2004), and participants in resilience studies have been expanded from children at risk to adults who are "in otherwise normal circumstances who are exposed to an isolated and potentially highly disruptive event" (Bonanno, 2004, p. 20). Regardless of the developmental stage, the antecedent of resilience as a dynamic process is the presence of one or more significant stressors (Pangallo, Zibarras, Lewis, \& Flaxman, 2015).

Trauma includes the "three E's" (Event, Experience, Effect) (Substance Abuse and Mental Health Services Administration, 2014):

Individual trauma results froman event, series of events, or set of circumstances that is experienced by an individual as physically or emotionally harmful or threatening and that has lasting adverse effects on the individual's functioning and physical, social, emotional, or spiritual well-being (p. 7).

If an individual experiences a highly traumatic event, one lasting adverse effect may include a memory of the stressful event that becomes a central component of personal identity (Berntsen \& Rubin, 2006). When individuals experience negative life events, they are at increased risk for psychopathologies (e.g., PTSD); some are less adversely affected by such events (Yehuda, 2004; Yehuda, Flory, Southwick, \& Charney, 2006). Because the stressful events or adversity do not necessarily cause lasting adverse effects, it would be more appropriate to add the adjective "potentially" before "traumatic events": Potentially Traumatic Events (PTEs). PTEs are defined as highly disruptive events that may potentially cause the exposed individual to develop psychopathology (Bonanno, 2004) (See Table 1 for the definitions of components of this concept analysis).

\section{Defining attributes of resilience}

The defining attributes of a concept are the characteristics of the concept that appear over and over again and "allow the analyst the broadest insight into the concept" (Walker \& Avant, 2011, p. 162). The defining attributes of resilience are individual and environmental resources that facilitate positive adaptation (Pangallo et al., 2015). It is proposed in this concept analysis that the specific defining attributes of resilience are: (1) egoresiliency, (2) emotion regulation, (3) social support, and (4) heredity.

\section{Ego-resiliency}

Ego-resiliency is a personality trait referring to the dynamic capacity to flexibly adapt to the changing demands of stressful experiences (Block \& Kremen, 1996) (Table 1). To avoid confusion, ego-resiliency should be used when resilience is referred to as a trait, whereas resilience as a dynamic process presupposes exposure to substantial adversity (Luthar, Cicchetti, \& Becker, 2000). Individuals with high ego-resiliency may show better adjustment following exposure to PTEs because of adaptive flexibility (Letzring, Block, \& Funder, 2005). For example, Fredrickson, Tugade,Waugh, and Larkin (2003) measured ego-resiliency prior to the September 11th terrorist attacks among college students and found that those scoring high on ego-resiliency experienced more positive emotions and endured fewer 
depressive symptoms following the attacks. Similarly, Galatzer-Levy and Bonanno (2013) indicated that ego-resiliency played a role in healthy adjustment among college students exposed to distressing events.

\begin{tabular}{|c|c|}
\hline Components & Definition \\
\hline \multicolumn{2}{|l|}{ Antecedent: } \\
\hline $\begin{array}{l}\text { Potentially traumatic event } \\
\text { (PTE) }\end{array}$ & $\begin{array}{l}\text { Highly disruptive event that may potentially cause the exposed individual } \\
\text { to develop psychopathology (Bonanno, 2004). }\end{array}$ \\
\hline \multicolumn{2}{|l|}{ Defining attributes: } \\
\hline Ego-resiliency & $\begin{array}{l}\text { A personality trait referring to the dynamic capacity to flexibly adapt to the } \\
\text { changing demands of stressful experiences (Block \& Kremen, 1996). }\end{array}$ \\
\hline Emotion regulation & $\begin{array}{l}\text { The capacity to shape which emotions one has, when one has emotions, } \\
\text { and how one expresses or experiences these emotions (Gross, 2014). }\end{array}$ \\
\hline Social support & $\begin{array}{l}\text { Different aspects of social relationships, including emotional, instrumental, } \\
\text { and informational support (House \& Kahn, 1985). Social support has } \\
\text { prominent facets, such as received (actual behaviors that network mem- } \\
\text { bers have performed) and perceived (the subjective perception that net- } \\
\text { work members are available to help, if needed) support (Kaniasty \& } \\
\text { Norris, 2009). }\end{array}$ \\
\hline Heredity & $\begin{array}{l}\text { Inheriting genes with different alleles through reproduction that may } \\
\text { influence individual variation in the observed traits, or phenotypes } \\
\text { (Lemery-Chalfant, 2010). }\end{array}$ \\
\hline \multicolumn{2}{|l|}{ Consequences: } \\
\hline $\begin{array}{l}\text { None to mild psychopatho- } \\
\text { logical symptoms }\end{array}$ & $\begin{array}{l}\text { Relatively stable and healthy levels of psychological and physical function- } \\
\text { ing following exposure to PTEs (Bonanno, 2004). }\end{array}$ \\
\hline $\begin{array}{l}\text { Positive adaptation (sense } \\
\text { of coherence) }\end{array}$ & $\begin{array}{l}\text { An indicator of positive adaptation is sense of coherence, which is a global } \\
\text { orientation to view the world, consisting of comprehensibility, managea- } \\
\text { bility, and meaningfulness (Antonovsky, 1987). }\end{array}$ \\
\hline
\end{tabular}

According to Block and Kremen (1996), ego-resiliency is the first conceptual use of the term that describes the remarkable phenomenon of human adaptability in psychology and can subsume other characteristics associated with resilience. Although resilience is associated with other psychological variables, including personal competence (Ahern, 2006; Connor \& Davidson, 2003; Friborg, Hjemdal, Rosenvinge, \& Martinussen, 2003; Simmons \& Yoder, 2013; Wagnild \& Young, 1993; Windle, Markland, \& Woods, 2008), self-enhancement (Gupta \& Bonanno, 2010), self-efficacy (Earvolino-Ramirez, 2007; Garcia-Dia, DiNapoli, Garcia-Ona, Jakubowski, \& O'Flaherty, 2013; Gillespie et al., 2007), and hardiness (Bartone, 1999; Zauszniewski, Bekhet, \& Suresky, 2010), ego-resiliency was selected as an attribute because it comprehensively and broadly captures the characteristics of resilient individuals. A review article indicates ego-resiliency is associated with flexibility, energy, assertiveness, humor, transcendent detachment, and a good capacity for affect regulation (Agaibi \& Wilson, 2005). 


\section{Emotion regulation}

Emotion regulation refers to the ability to shape which emotions one has, when emotions are generated, and to decide how one expresses or experiences those emotions (Gross, 2014) (Table 1). It involves two related strategies: (1) antecedent-focused reappraisal, which involves construing a potentially emotional situation to change its emotional impact, and (2) response-focused suppression, in which emotion expressive behavior is modified or inhibited (Gross \& John, 2003). Emotion regulation is used to decrease or increase either the magnitude or the duration of negative or positive emotion (Gross, 2014). Resilient individuals often use positive emotions, such as humor and optimism, to bounce back from stressful experiences (Tugade \& Fredrickson, 2004). Empirical evidence indicates that resilient individuals benefit from positive emotions to adjust to PTEs, such as the 9/11 terrorist attacks (Fredrickson et al., 2003), spousal loss (Ong, Fuller-Rowell, \& Bonanno, 2010), and captivity endured by Vietnam prisoners of war (Southwick \& Charney, 2012a). It appears positive emotions protect against the unfavorable consequences of PTEs by decreasing the autonomic arousal provoked by negative emotions (Feder, Nestler, Westphal, \& Charney, 2010). More specifically, according to the broaden-and-build theory (Fredrickson, 2001), "experiences of positive emotions broaden people's momentary thought-action repertoires, which in turn serves to build their enduring personal resources, ranging from physical and intellectual resources to social and psychological resources" (p. 218), which may help individuals stay resilient.

Emotion regulation is sometimes distinguished from coping because the predominant focus of coping is on decreasing negative affect for much larger periods of time (Gross, 2014). The literature certainly suggests that resilient individuals use active coping (Haglund, Cooper, Southwick, \& Charney, 2007). Coping itself is also very complex, as "what works in one situation may not in another, what works for one individual may not for another, and what works at one point in time may not at another" (Norris et al., 2002, p. 238). For the purpose of conceptual clarification, coping (and the psychoanalytic literature including defensive mechanisms) may be considered as "historical antecedents to the contemporary study of emotion regulation" (Sheppes \& Gross, 2013, p. 393). In addition, a newer concept, "regulatory flexibility" (Bonanno \& Burton, 2013), which is defined as the matching of emotion regulation strategy (repertoire) to environmental circumstance (context) is emerging. In this paper, emotion regulation is selected as a more comprehensive term rather than defensive mechanisms or regulatory flexibility.

\section{Social support}

There are three main types of social support: (1) emotional support, which supports esteem, affect, trust, concern, and listening; (2) instrumental support, which involves concrete actions that network members may perform, such as lending money; and (3) informational support, which consists of advice, suggestion, directives, and information (House \& Kahn, 1985) (Table 1). Furthermore, social support has prominent facets, such as received support, which refers to actual behaviors that network members have performed, and perceived support, which refers to the subjective perception that network members are available to help if needed (Kaniasty \& Norris, 2009). Evidence indicates that received and perceived social support may play a distinct role in adjustment to PTEs (Bonanno, Brewin, Kaniasty, \& 
Greca, 2010). For example, perceived social support was found to be related to factors, such as age, education, and perceived community unity in addition to received social support in the aftermath of disaster (Kaniasty, 2012).

Social support helps individuals to remain resilient in the face of PTEs (Helgeson \& Lopez, 2010; Perry, 1983; Yehuda et al., 2006). Research has shown that social support reduces the adverse psychological effects of PTEs, such as combat (Stretch, 1986), sexual assault (Golding, Siege, Sorenson, Burnam, \& Stein, 1989), and terrorist attacks (Bonanno, Galea, Bucciarelli, \& Vlahov, 2007), by decreasing negative cognitive reappraisal (Fontana, Kerns, Rosenberg, \& Colonese, 1989). Correspondingly, a meta-analysis reveals that lack of social support is the second most important risk factor for predicting PTSD, following trauma severity (Brewin, Andrews, \& Valentine, 2000). In addition, the importance of social support is validated by numerous longitudinal resilience studies around the world, including the Kauai Longitudinal Study, the British Cohort Study, and the Australian Temperament Project (as cited in Werner, 2013). Therefore, social support can be considered as another defining attribute of resilience.

\section{Heredity}

Resilience has a heritable component and is influenced by more than one gene (Cicchetti \& Blender, 2006). Heredity means inheriting genes with different alleles through reproduction that may influence individual variation in the observed traits, or phenotypes (LemeryChalfant, 2010) (Table 1). Because brain circuitries are involved in the stress response and reward experience (e.g., mesolimbic reward pathway), they may play an important role in resilience (Rutten et al., 2013). Several candidate genes involved in brain circuitry regulation include the Serotonin-Transporter-Linked Polymorphic Region (5-HTTLPR), Brain-Derived Neurotrophic Factor (BDNF), and Catechol-O-Methyltransferase (COMT) genes (Feder, Nestler, \& Charney, 2009; Wu et al., 2013). In addition, other genes that regulate the hypothalamic-pituitary-adrenal axis function, such as corticotrophin-releasing hormone receptor (CRHR1) gene and FK506 Binding Protein 5 gene, may also influence resilience to PTEs, including child maltreatment or abuse (Gillespie, Phifer, Bradley, \& Ressler, 2009).

Variance in ego-resiliency was largely explained by additive genetic factors $(77 \%$ in boys and 70\% in girls) (Waaktaar \& Torgersen, 2012). Taylor et al. (2014) investigated the development of ego-resiliency in relation to observed parenting and the serotonin transporter genes and found that the S10 haplotype of the serotonin transporter genes (i.e., the combination of two variants: the $\mathrm{S}$ allele of 5-HTTLPR and the 10-repeat allele of Serotonin Transporter Intron 2 [STin2]) was negatively associated with initial levels of ego-resiliency. In addition to the serotonin transporter gene, other genes such as CRHR1, Dopamine Receptor D4, and Oxytocin Receptor (OXTR) genes may also influence the development of egoresiliency (Cicchetti \& Rogosch, 2012).

Similarly, emotion regulation is also influenced by heredity. It is estimated that the heritability of emotion regulation is $0.45-0.55$ (Weinberg, Venables, Proudfit, \& Patrick, 2015). Candidate genes associated with emotion regulation include 5-HTTLPR, COMT, MonoAmine Oxidase A (MAOA), and OXTR (Canli, Ferri, \& Duman, 2009; Hawn, Overstreet, Stewart, \& Amstadter, 2015). Evidence also suggests that emotion regulation is developed through learning. For example, Ford, Mauss, Troy, Smolen, and Hankin (2014) found that 
children who learned effective emotion regulation did not exhibit increased depressive symptoms, despite the fact that they were considered as "at-risk" due to the possession of the short allele of 5-HTTLPR. Therapeutic interventions, such as cognitive behavior therapy and mindful meditation, can enhance emotion regulation by strengthening the prefrontal cortex regulation of limbic and brainstem systems (Holzel et al., 2011; Southwick \& Charney, 2012b), thereby promoting resilience (Feldman, Hayes, Kumar, Greeson, \& Laurenceau, 2006; Henje Blom et al., 2014; McLaughlin, Mennin, \& Farach, 2007; Southwick \& Charney, 2012b; Thompson, Arnkoff, \& Glass, 2011).

Gene expression is highly responsive to the environment (Lemery-Chalfant, 2010). Investigation of Gene by Environment $(\mathrm{G} \times \mathrm{E})$ interaction has recently been incorporated in the field of resilience studies (Bowes \& Jaffee, 2013; Kim-Cohen \& Gold, 2009; Kim-Cohen \& Turkewitz, 2012; Rutter, 2012). A G × E interaction occurs when the effect of exposure to an environmental risk factor on health and behavior is moderated by specific gene variants (Caspi, Hariri, Holmes, Uher, \& Moffitt, 2010; Moffitt, Caspi, \& Rutter, 2006), or conversely, when the effect of specific genes is moderated by the environment (Caspi \&Moffitt, 2006; Wermter et al., 2010). When resilience is investigated from the $G \times E$ interaction aspect, resilience can be conceptualized in terms of "reactivity" (Davydov et al., 2010). Namely, individuals who carry "reactive" alleles may be disproportionately influenced by both negative and positive environments ("differential susceptibility model") (Ellis, Boyce, Belsky, Bakermans-Kranenburg, \& van Ijzendoorn, 2011). To further conceptualize reactivity, Pluess (2015) identified that maintaining the level of functioning when exposed to negative influence is called "resilience," whereas it is "vantage resistance" when exposed to positive influence. Worsening of the level of functioning when exposed to negative influence is called "vulnerability," whereas improving the level of functioning when exposed to positive influence is "vantage sensitivity" (Pluess, 2015). A meta-analysis supports the differential susceptibility model that individuals with the reactive allele(s) of 5-HTTLPR, S allele(s), are more negatively affected by adversity but also benefited more from positive environmental exposures (van Ijzendoorn, Belsky, \& Bakermans-Kranenburg, 2012). In other words, individuals with less reactive alleles (e.g., the L allele of 5-HTTLPR) may be more "resilient" when exposed to PTEs, whereas the response of those with more reactive alleles (e.g., the $\mathrm{S}$ allele of 5-HTTLPR) may depend on the environmental context.

\section{Consequences of resilience}

Consequences are the events or incidents that arise as a result of the occurrence of the concept (i.e., outcomes of the concept) (Walker \& Avant, 2011). Some researchers (e.g., Luthar \& Zelazo, 2003) argue that the outcome of resilience cannot be directly measured but only inferred. For example, if a school-age child exposed to adversity meets developmental tasks (e.g., good academic performance) that are considered appropriate for his or her age, gender, culture, and period in history, then the child may be described as "resilient" (Masten, Monn, \& Supkoff, 2011). Other investigators describe an individual as "resilient" if he or she remains free from mental health disorders or impairment following exposure to adversity (Alim et al., 2008; Bonanno, 2004). Furthermore, other scientists (e.g., Pangallo et al., 2015) propose that resilient outcomes are quantifiable and measurable by using psychometrically validated instruments, such as the Connor-Davidson Resilience Scale 
(Connor \& Davidson, 2003) and Sense of Coherence Scale (Antonovsky, 1993). Generally, the consequence of resilience is positive adjustment or adaptation relative to developmental life stage (Pangallo et al., 2015). Because there is no simple method to determine what the outcomes of resilience are and no agreed-upon outcome measures, two main consequences of resilience are proposed in this paper: (1) none to mild psychopathological symptoms, and (2) positive adaptation.

\section{None to mild psychopathological symptoms}

According to the Diagnostic and Statistical Manual of Mental Disorders-5th edition (DSM-5) (American Psychiatric Association, 2013), the development of psychopathology may be suspected if the disturbance following exposure to PTEs "causes clinically significant distress or impairment in social, occupational, or other important areas of functioning" (p. 272). If the duration of psychopathological symptoms (e.g., avoidance) last three days to a month, it may be diagnosed as Acute Stress Disorder; if the duration lasts more than a month, it may be diagnosed as PTSD. Nonetheless, if the symptoms are not severe enough to cause disturbance in daily functioning, or if the symptoms resolve within a few days following exposure to PTEs, then the person may be described as resilient. In other words, a resilient outcome may be manifested as relatively stable and healthy levels of psychological and physical functioning following exposure to PTEs (Bonanno, 2004) (Table 1).

When resilience is considered as longitudinal consequences (e.g., measuring psychopathological symptoms at one, three, and six months after the exposure to PTEs), the severity and duration of psychopathological symptoms may be expressed as trajectories. Based on empirical evidence, Bonanno and Diminich (2013) identify the six most common prototypical outcome trajectories following PTEs: (1) minimal-impact resilience (consistently low levels of psychopathological symptoms before and after PTE exposure), (2) recovery (moderate-to-severe psychopathological symptoms occurring for several months after the PTE, then gradually declining to baseline levels of adjustment over the course of one or two years), (3) chronic (psychopathological symptoms after the occurrence of the PTE lasting several years or more), (4) delayed (increased psychopathological symptoms over time), (5) continuous (prior psychopathological symptoms that continue after PTE exposure), and (6) improved (psychopathological symptoms before PTE exposure that decrease greatly after the PTE). For example, deRoon-Cassini, Mancini, Rusch, and Bonanno (2010) investigated trajectories of resilience following traumatic injury (e.g., automobile crash) and identified four distinct patterns by measuring PTSD-like symptoms over six months: (1) minimal-impact resilience (i.e., "low symptom," 59\%), (2) recovery (13\%), (3) chronic $(22 \%)$, and (4) delayed (6\%). Similar patterns of trajectories of resilience have been supported in a variety of PTEs, including the 1999 floods in Mexico and the terrorist attacks in New York (Norris, Tracy, \& Galea, 2009), breast cancer among Chinese women (Lam et al., 2010), spinal cord injury (Bonanno, Kennedy, Galatzer-Levy, Lude, \& Elfstrom, 2012), and campus mass shooting (Orcutt, Bonanno, Hannan, \& Miron, 2014).

\section{Positive adaptation}

Comparable to the definition of health by World Health Organization (1948), which is "a state of complete physical, mental and social well-being and not merely the absence of disease 
or infirmity" (p. 1), resilience is not simply the absence of psychopathology (Almedom \& Glandon, 2007; Vaillant, 2003). Rather than viewing resilience as dichotomy (i.e., either one has it or not) or average scores (i.e., comparing exposed to nonexposed) (Bonanno, Westphal, \& Mancini, 2011), resilience may be considered as a continuum of adaptation (Agaibi \& Wilson, 2005; Simmons \& Yoder, 2013). The presence of psychopathological symptoms may indicate negative adaptation. However, the absence of psychopathology does not necessarily mean positive adaptation.

Positive adaptation can be measured by other instruments (Davydov et al., 2010; Pangallo et al., 2015), such as Connor-Davidson Resilience Scale (Connor \& Davidson, 2003) and Mental Health Inventory (Veit \& Ware, 1983). However, Sense of Coherence (SOC) was selected as an outcome in this concept analysis because SOC may be most inclusive of these similar measurements of positive adaptation (Almedom, 2005). SOC is defined as:

... a global orientation that expresses the extent to which one has a pervasive, enduring though dynamic feeling of confidence that (1) stimuli deriving from one's internal and external environments in the course of living are structured, predictable, and explicable; (2) the resources are available to one to offset the demands posed by these stimuli; and (3) these demands are challenges, worthy of investment and engagement (Antonovsky, 1987, p. 19) (Table 1).

SOC is quantifiable using the SOC Scale (Antonovsky, 1993), which consists of three subscales: (1) comprehensibility (cognitive), (2) manageability (behavioral), and (3) meaningfulness (motivational component). Although these three components are highly related to one another, meaningfulness may be considered as the most important, followed by compressibility and manageability (Horsburgh \& Ferguson, 2012). Antonovsky (1993) emphasizes that SOC is not a personality trait or a coping strategy. Rather, SOC is shaped by life situation, such as culture and life experiences, and it ultimately functions as movement toward health (Antonovsky, 1979; Benz, Bull, Mittelmark, \& Vaandrager, 2014; Horsburgh \& Ferguson, 2012).

As an individual gains more life experiences, he or she will begin to view the world as coherent and predictable (Horsburgh \& Ferguson, 2012). Although Antonovsky initially anticipated SOC to stabilize around the age of 30, emerging evidence suggests that SOC continuously develops until the mid-70s (Nilsson, Leppert, Simonsson, \& Starrin, 2010). Systematic reviews reveal that stronger SOC is linked to better quality of life (Eriksson \& Lindstrom, 2007) and better perceived health, especially mental health (Eriksson \& Lindstrom, 2006). Additionally, an integrative review identifies SOC as one of resilience indicators in family members of persons with mental illness (Zauszniewski et al., 2010). Family members who possess resilience indicators, including SOC, can better overcome adversity associated with caring for a family member with a mental illness and experience positive health outcomes, such as greater psychological well-being (Zauszniewski et al., 2010). 


\section{Cases of resilience}

Walker and Avant (2011) encourage the concept analyst to apply the concept of interest and identify model, borderline, and contrary cases. A model case refers to an example of the concept that demonstrates all the defining attributes of the concept. A borderline case is an example that contains most defining attributes but not all of them. A contrary case is an example of "not the concept" (Walker \& Avant, 2011, p. 166). The attributes of the concept of resilience are indicated within the parenthesis in each case.

\section{Model case}

The story of Admiral Robert Shumaker (Southwick \& Charney, 2012c) was analyzed as a model case because evidence of high ego-resiliency, adaptive emotion regulation, and strong perception of social support in a traumatic situation can be detected in his story. Admiral Shumaker was imprisoned as a prisoner of war (POW) in North Vietnamese prisons for nine years (PTE). He understood the human's need to bond with one another (strong social support). From his solitary confinement cell, he was only able to see a fellow prisoner who was taken to the same latrine he used at a different time of day. To communicate with this prisoner, he wrote a message on toilet paper and left it for him since the guards rarely went in to this area. The message said: "Welcome to the Hanoi Hilton" (high ego-resiliency) and told him to show a shared signal on his way out of the latrine (Southwick \& Charney, 2012c, p. 100). When Admiral Shumakerwitnessed his fellowprisoner following this command, he felt, ". . . it was a happy day for me when I made contact" (Southwick \& Charney, 2012c, p. 100). Judging from his selected word, "happy," it appears his emotions were well regulated by generating positive emotions (adaptive emotion regulation) even while in prison.

Despite such brutal conditions, his psychopathological symptoms were minimal. When three other POWs were added to his cell, Admiral Shumaker realized the importance of a communication method that he later called the "Tap Code." When they were separated into different cells, each one spread the code to other prisoners, which led to the formation of the Tap Code as the backbone of the prisoners' communication network within months. For his crucial role in communication among prisoners that proved to be a lifesaver for hundreds of POWs, Admiral Shumaker earned the name "Martini Mixer." It appears he had a strong SOC as he believed that social support and the Tap Code communication system was possible (comprehensibility), his mission to promote communications among POWs was important (meaningfulness), and the imprisonment was survivable (manageability). Although we do not have specific genetic information about Admiral Shumaker, we can hypothesize that, because he was in a very traumatic situation and was resilient, he had the less reactive alleles for genes that influence resilience (heredity).

\section{Borderline case}

This is a fictional story to demonstrate a borderline case of resilience. Mike was an undergraduate pre-law student. After a significant disagreement, his girlfriend discontinued their relationship (PTE). 
His mind was fixated on the loss of his girlfriend (low ego-resiliency). To suppress his sad feelings, Mike started to consume large amounts of alcohol (maladaptive emotion regulation). Although his family and friends attempted to console him (strong social support), he answered only a few of their phone calls and messages because it was too stressful to talk about the loss of this relationship.

He lost motivation to attend class and experienced depressive symptoms (moderate psychopathological symptoms). As a result, he received a low grade in several classes and was placed on academic probation. Even though he thought he could never find another girlfriend, he still viewed a law career as a meaningful goal (moderate sense of coherence). The notice of academic probation led him to seek counseling to address his depression. Mike was able to achieve better grades the following semester and was in good academic standing. He started to date again but continued to dwell on the loss of his previous romantic relationship. Although his genetic information is unknown, we can hypothesize that he had more susceptible alleles that were related to less resilience in a negative environment (i.e., loss of a romantic partner) (heredity).

\section{Contrary case}

This is a fictional story to demonstrate a contrary case of resilience. Sarah was a college student majoring in marketing. On a Friday night, she joined a party where she consumed too much alcohol and was sexually assaulted by an acquaintance (PTE).

She felt overwhelmed and remained passive (low ego-resiliency). She did not disclose this incident to her friends, family, school authorities, or police (weak perceived social support) because she was afraid of the consequences of reporting the assault. She suppressed her fearful feelings by being socially withdrawn (maladaptive emotion regulation).

She started experiencing flashbacks, panic attacks, and insomnia (severe psychopathological symptoms). She experienced significant guilt for drinking too much and not resisting her attacker, and she thought others would be better off without her (weak sense of coherence). Then, she overdosed with over-the-counter medications. She was later found by her roommate, taken to the Emergency Room, and hospitalized for treatment. Although no genetic information is available, we can hypothesize that she had more reactive alleles to the negative environment she encountered (heredity).

\section{Discussion}

There is no single agreed-upon definition of resilience in the clinical or scientific literature (Fletcher \& Sarkar, 2013; Southwick \& Charney, 2012b; Southwick et al., 2011). According to Walker and Avant (2011), the concept analyst identifies the purpose of the analysis and identifies the elements that allow the analyst to have the broadest insight into the concept. Given this information, the antecedent of resilience proposed is PTE; the defining attributes are ego-resiliency, emotion regulation, social support, and heredity; and the consequences are none to mild psychopathological symptoms and positive adaptation (Table 1). As a result of this analysis, resilience is defined as a dynamic process of positive adaptation following exposure to PTEs, facilitated by ego-resiliency, emotion regulation, social support, and 
heredity, and evidenced by none to mild psychopathological symptoms and positive adaptation through development of a SOC.

Most researchers who conducted a concept analysis on resilience identified one antecedent simply as "adversity" (Dyer \& McGuinness, 1996; Earvolino-Ramirez, 2007; Felten \& Hall, 2001; Garcia-Dia et al., 2013; Gillespie et al., 2007; Olsson, Bond, Burns, Vella-Brodrick, \& Sawyer, 2003; Windle, 2011) or "life event" (Simmons \& Yoder, 2013). In contrast, the term, "potentially traumatic event," is applied in this paper, indicating individual variability in response to negative life events.

For the defining attributes of resilience, (1) ego-resiliency, (2) emotion regulation, (3) social support, and (4) heredity are proposed. Ego-resiliency is considered as a personality trait that contributes to resilience, a dynamic process, when exposed to PTEs. Individuals with high ego-resiliency would generate more positive emotions and set into motion a "resilience cascade" (Ong, Bergeman, \& Boker, 2009, p. 1786), attracting even more social resources. In addition, heredity is identified as a defining attribute of resilience because genes may substantially influence behavioral health (Plomin et al., 2013), including resilience (Feder et al., 2009; Wu et al., 2013).

For the consequences, although psychological distress is considered as a normal reaction immediately following exposure to PTEs, resilient individuals would experience none to mild psychopathological symptoms and manage such symptoms in a relatively short period (Bonanno \& Diminich, 2013). Because resilience is not merely the absence of the psychopathological symptoms, SOC can be evidence of positive adaptation (Almedom \& Glandon, 2007). Individuals are constantly in situations of stress, tension, challenge, response, and resolution (Horsburgh \& Ferguson, 2012), and an individual's SOC would continue developing throughout the lifespan (Nilsson et al., 2010).

To the authors' knowledge, this is the first concept analysis to include heredity as a defining attribute of resilience. Nurse scientists are encouraged to conduct genetic/genomic research (International Society of Nurses in Genetics, 2016) because nurses have a holistic perspective on human health and play an important role in applying genomic discoveries to improve methods for patient assessment and intervention (Lee, Gill, Barr, Yun, \& Kim, 2017). Because emerging evidence indicate resilience is influenced by genetics (Feder et al., 2009), heredity was included as a defining attribute of the concept.

It has been debated if resilience is best categorized as an individual trait, a process, an outcome, or all of the above (Reich et al., 2010). While performing this concept analysis, it was found that resilience as an individual trait and resilience as a process/outcome are used interchangeably in the literature, causing a troublesome confusion among researchers. This concept analysis made it clearer that, when referring to a personality trait, the term resiliency or more specifically ego-resiliency instead of resilience is best used (Luthar et al., 2000; Mancini \& Bonanno, 2010). This concept analysis identified that resilience outcomes may include two components: (1) none to mild psychopathological symptoms and (2) positive adaptation. The rationale for this conceptualization is because resilience is notmerely the absence of psychopathology but also is positive adaptation (Almedom \& Glandon, 2007). This concept analysis emphasizes that, if only none to mild psychopathological symptoms are the focus, it tells only part of the story of resilience. 
Three major limitations are identified. First, due to the tentativeness of concepts (Walker \& Avant, 2011), the usefulness of this concept analysis may change over time as the scientific and this analyst's knowledge develop. Second, this concept analysis may have failed to include some important components of resilience, especially the defining attributes, due to a reductionistic approach. For example, Pangallo et al. (2015) derived 16 themes associated with resilience, and Johnson et al. (2011) identified 26 related constructs to resilience. However, only four defining attributes (ego-resiliency, emotion regulation, social support, and heredity) were identified in this analysis because they gave the authors the broadest insight into the concept of resilience as a response to PTEs. Third, the antecedent of resilience in this concept analysis, PTEs, is described as a generic event that may commonly happen in the developed countries, such as the United States and Japan. It would be important to consider the context of PTEs (Masten \& Narayan, 2012) as well as the cultural context unique to the individual to more comprehensively understand resilience (Bell, 2011; Block \& Block, 2006; Castro \& Murray, 2010).

\section{Conclusions}

A concept analysis of resilience reveals: the antecedent is PTEs; the defining attributes are ego-resiliency, emotion regulation, social support, and heredity; and the consequences are none to mild psychopathological symptoms and positive adaptation that can be manifested as SOC (Table 1). To the authors' knowledge, this is the first concept analysis of resilience that includes ego-resiliency, emotion regulation, and heredity as defining attributes, and SOC as a consequence. As scientific knowledge about resilience develops, the antecedent, defining attributes, and consequences may change. A better understanding of resilience and its relationship with intrapersonal (e.g., heredity, ego-resiliency) and environmental (e.g., social support) variables would help nurse clinicians and researchers develop interventions that facilitate an individual's potential for resilience when exposed to PTEs.

\section{References}

Agaibi, C. E., \& Wilson, J. P. (2005). Trauma, PTSD, and resilience: A review of the literature. Trauma Violence Abuse, 6(3), 195-216. doi:10.1177/1524838005277438

Agnes, M. (2000). Webster's new world college dictionary (4th ed.). Foster City, CA: IDG Books World, Inc.

Ahern, N. R. (2006). Adolescent resilience: An evolutionary concept analysis. Journal of Pediatric Nursing, 21(3), 175-185. doi:10.1016/j.pedn.2005.07.009

Alim, T. N., Feder, A., Graves, R. E., Wang, Y., Weaver, J., Westphal, M., . . Charney, D. S. (2008). Trauma, resilience, and recovery in a high-risk African-American population. American Journal of Psychiatry, 165(12), 1566-1575. doi:10.1176/appi.ajp.2008.07121939

Almedom, A. M. (2005). Resilience, hardiness, sense of coherence, and posttraumatic growth: All paths leading to "light at the end of the tunnel"? Journal of Loss and Trauma, 10(3), 253-265. doi:10.1080/15325020590928216 
Almedom, A. M., \& Glandon, D. (2007). Resilience is not the absence of PTSD any more than health is the absence of disease. Journal of Loss and Trauma, 12(2), 127-143. doi:10.1080/15325020600945962

American Psychiatric Association. (2013). Diagnostic and statistical manual of mental disorders (5th ed.). Arlington, VA: American Psychiatric Association.

Antonovsky,A. (1979). Health, stress, and coping. San Francisco, CA: Jossey-Bass.

Antonovsky, A. (1987). Unraveling the mystery of health: How people manage stress and stay well. San Francisco, CA: Jossey-Bass.

Antonovsky, A. (1993). The structure and properties of the sense of coherence scale. Social Science and Medicine, 36(6), 725-733.

Bartone, P. T. (1999). Hardiness protects against war-related stress in Army Reserve forces. Consulting Psychology Journal: Practice and Research, 51(2), 72-82. doi:10.1037/1061-4087.51.2.72

Bell, C. C. (2011). Trauma, culture, and resiliency. In S. M. Southwick, B. T. Litz, D. Charney, \& M. J. Friedman (Eds.), Resilience and mental health: Challenges across the lifespan (pp. 176-187). New York: Cambridge University Press.

Benz, C., Bull, T., Mittelmark, M., \& Vaandrager, L. (2014). Culture in salutogenesis: The scholarship of Aaron Antonovsky. Global Health Promotion, 21(4), 16-23. doi:10.1177/1757975914528550

Berntsen, D., \& Rubin, D. C. (2006). The centrality of event scale: A measure of integrating a trauma into one's identity and its relation to posttraumatic stress disorder symptoms. Behaviour Research and Therapy, 44(2), 219-231. doi:10.1016/j.brat.2005.01.009

Block, J., \& Block, J. H. (2006). Venturing a 30-year longitudinal study. American Psychologist, 61(4), 315-327. doi:10.1037/0003-066X.61.4.315

Block, J., \& Kremen, A. M. (1996). IQ and ego-resiliency: Conceptual and empirical connections and separateness. Journal of Personality and Social Psychology, 70(2), 349-361.

Bonanno, G. A. (2004). Loss, trauma, and human resilience: Have we underestimated the human capacity to thrive after extremely aversive events? American Psychologist, 59(1), 20-28. doi:10.1037/ 0003-066X.59.1.20

Bonanno, G. A., Brewin, C. R., Kaniasty, K., \& Greca, A. M. (2010). Weighing the costs of disaster: Consequences, risks, and resilience in individuals, families, and communities. Psychological Science in the Public Interest, 11(1), 1-49. doi:10.1177/1529100610387086

Bonanno, G. A., \& Burton, C. L. (2013). Regulatory flexibility: An individual differences perspective on coping and emotion regulation. Perspectives on Psychological Science, 8(6), 591-612. doi:10.1177/1745691613504116

Bonanno, G. A., \& Diminich, E. D. (2013). Annual Research Review: Positive adjustment to adversity - trajectories of minimal-impact resilience and emergent resilience. Journal of Child Psychology and Psychiatry and Allied Disciplines, 54(4), 378-401. doi:10.1111/jcpp.12021

Bonanno, G. A., Galea, S., Bucciarelli, A., \& Vlahov, D. (2007). What predicts psychological resilience after disaster? The role of demographics, resources, and life stress. Journal of Consulting and Clinical Psychology, 75(5), 671-682. doi:10.1037/0022-006X.75.5.671

Bonanno, G. A., Kennedy, P., Galatzer-Levy, I. R., Lude, P., \& Elfstrom, M. L. (2012). Trajectories of resilience, depression, and anxiety following spinal cord injury. Rehabilitation Psychology, 57(3), 236-247. doi:10.1037/a0029256

Bonanno, G. A., Westphal, M., \& Mancini, A. D. (2011). Resilience to loss and potential trauma. Annual Review of Clinical Psychology, 7, 511-535. doi:10.1146/annurev-clinpsy-032210-104526

Bowes, L., \& Jaffee, S. R. (2013). Biology, genes, and resilience: Toward a multidisciplinary approach. Trauma Violence Abuse, 14(3), 195-208. doi:10.1177/1524838013487807 
Brewin, C. R., Andrews, B., \& Valentine, J. D. (2000). Meta-analysis of risk factors for posttraumatic stress disorder in trauma-exposed adults. Journal of Consulting and Clinical Psychology, 68(5), 748-766.

Canli, T., Ferri, J., \& Duman, E. A. (2009). Genetics of emotion regulation. Neuroscience, 164(1), 43-54. doi:10.1016/j.neuroscience.2009.06.049

Carver, C. S. (1998). Resilience and thriving: Issues, models, and linkages. Journal of Social Issues, 54(2), 245-266.

Caspi, A., Hariri, A. R., Holmes, A., Uher, R., \& Moffitt, T. E. (2010). Genetic sensitivity to the environment: The case of the serotonin transporter gene and its implications for studying complex diseases and traits. American Journal of Psychiatry, 167(5), 509-527. doi:10.1176/appi.ajp.2010 .09101452

Caspi, A., \& Moffitt, T. E. (2006). Gene-environment interactions in psychiatry: Joining forces with neuroscience. Nature Reviews: Neuroscience, 7(7), 583-590. doi:10.1038/nrn1925

Castro, F. G., \& Murray, K. E. (2010). Cultural adaptation and resilience. In J. W. Reich, A. J. Zautra, \& J. S. Hall (Eds.), Handbook of adult resilience (pp. 375-403). New York: The Guilford Press.

Cicchetti, D. (2010). Resilience under conditions of extreme stress: A multilevel perspective. World Psychiatry, 9(3), 145-154.

Cicchetti, D., \& Blender, J. A. (2006). A multiple-levels-of-analysis perspective on resilience: Implications for the developing brain, neural plasticity, and preventive interventions. Annals of the New York Academy of Sciences, 1094, 248-258. doi:10.1196/annals.1376.029

Cicchetti, D., \& Rogosch, F. A. (2012).Gene $\times$ Environment interaction and resilience: Effects of child maltreatment and serotonin, corticotropin releasing hormone, dopamine, and oxytocin genes. Development and Psychopathology, 24(2), 411-427. doi:10.1017/S0954579412000077

Connor, K. M., \& Davidson, J. R. (2003). Development of a new resilience scale: The ConnorDavidson Resilience Scale (CD-RISC). Depression and Anxiety, 18(2), 76-82. doi:10.1002/da.10113

Davydov, D. M., Stewart, R., Ritchie, K., \& Chaudieu, I. (2010). Resilience and mental health. Clinical Psychology Review, 30(5), 479-495. doi:10.1016/j.cpr.2010.03.003

Den, R., Yagi, G., Tanabe, H., \& Watanabe, K. (2008). Resilience in mental and behavioral disorder. Japanese Journal of Clinnical Psychiatry, 37(4), 349-355.

Denhardt, J., \& Denhardt, R. (2010). Building organizational resilience and adaptive management. In J. W. Reich, A. J. Zautra, \& J. S. Hall (Eds.), Handbook of adult resilience (pp. 333-349). New York: The Guilford Press.

deRoon-Cassini, T. A., Mancini, A. D., Rusch, M. D., \& Bonanno, G. A. (2010). Psychopathology and resilience following traumatic injury: A latent growth mixture model analysis. Rehabilitation Psychology, 55(1), 1-11. doi:10.1037/a0018601

Dictionaries, The American Heritage. (1995). Roget's II the new thesaurus (3rd ed.). Boston, MA: Houghton Mifflin Company.

Dyer, J. G., \& McGuinness, T. M. (1996). Resilience: Analysis of the concept. Archives of Psychiatric Nursing, 10(5), 276-282.

Earvolino-Ramirez, M. (2007). Resilience: A concept analysis. Nursing Forum, 42(2), 73-82. doi:10.1111/ j.1744-6198.2007.00070.x

Ellis, B. J., Boyce, W. T., Belsky, J., Bakermans-Kranenburg, M. J., \& van Ijzendoorn, M. H. (2011). Differential susceptibility to the environment: An evolutionary-neurodevelopmental theory. Development and Psychopathology, 23(1), 7-28. doi:10.1017/S0954579410000611 
Eriksson, M., \& Lindstrom, B. (2006). Antonovsky's sense of coherence scale and the relation with health: A systematic review. Journal of Epidemiology and Community Health, 60(5), 376-381. doi:10.1136/jech.2005.041616

Eriksson, M., \& Lindstrom, B. (2007). Antonovsky's sense of coherence scale and its relation with quality of life: A systematic review. Journal of Epidemiology and Community Health, 61(11), 938-944. doi:10.1136/jech.2006.056028

Feder, A., Nestler, E. J., \& Charney, D. S. (2009). Psychobiology and molecular genetics of resilience. Nature Reviews: Neuroscience, 10(6), 446-457. doi:10.1038/nrn2649

Feder, A., Nestler, E. J., Westphal, M., \& Charney, D. S. (2010). Psychological mechanisms of resilience to stress. In J. W. Reich, A. J. Zautra, \& J. S. Hall (Eds.), Handbook of adult resilience (pp. 3554). New York: The Guilford Press.

Feldman, G., Hayes, A., Kumar, S., Greeson, J., \& Laurenceau, J. (2006). Mindfulness and emotion regulation: The development and initial validation of the Cognitive and Affective Mindfulness Scale-Revised (CAMS-R). Journal of Psychopathology and Behavioral Assessment, 29(3), 177. doi:10.1007/ s10862-006-9035-8

Felten, B. S., \& Hall, J. M. (2001). Conceptualizing resilience in women older than 85: Overcoming adversity from illness or loss. Journal of Gerontological Nursing, 27(11), 46-53.

Fletcher, D., \& Sarkar, M. (2013). Psychological resilience: A review and critique of definitions, concepts, and theory. European Psychologist, 18(1), 12-23. doi:10.1027/1016-9040/a000124

Fontana, A. F., Kerns, R. D., Rosenberg, R. L., \& Colonese, K. L. (1989). Support, stress, and recovery from coronary heart disease: A longitudinal causal model. Health Psychology, 8(2), 175-193.

Ford, B. Q., Mauss, I. B., Troy, A. S., Smolen, A., \& Hankin, B. (2014). Emotion regulation moderates the risk associated with the 5-HTT gene and stress in children. Emotion, 14(5), 930-939. doi:10.1037/ a0036835

Fredrickson, B. L. (2001). The role of positive emotions in positive psychology: The broaden-andbuild theory of positive emotions. American Psychologist, 56(3), 218-226.

Fredrickson, B. L., Tugade, M. M., Waugh, C. E., \& Larkin, G. R. (2003). What good are positive emotions in crises? A prospective study of resilience and emotions following the terrorist attacks on the United States on September 11th, 2001. Journal of Personality and Social Psychology, 84(2), 365-376.

Friborg, O., Hjemdal, O., Rosenvinge, J. H., \& Martinussen, M. (2003). A new rating scale for adult resilience: What are the central protective resources behind healthy adjustment? International Journal of Methods in Psychiatric Research, 12(2), 65-76.

Galatzer-Levy, I. R., \& Bonanno, G. A. (2013). Heterogeneous patterns of stress over the four years of college: Associations with anxious attachment and ego-resiliency. Journal of Personality, 81(5), 476-486. doi:10.1111/jopy.12010

Garcia-Dia, M. J., DiNapoli, J. M., Garcia-Ona, L., Jakubowski, R., \& O’Flaherty, D. (2013). Concept analysis: Resilience. Archives of Psychiatric Nursing, 27(6), 264-270. doi:10.1016/j.apnu.2013.07.003

Garmezy, N. (1993). Children in poverty: Resilience despite risk. Psychiatry, 56(1), 127-136.

Gillespie, B. M., Chaboyer, W., \& Wallis, M. (2007). Development of a theoretically derived model of resilience through concept analysis. Contemporary Nurse, 25(1-2), 124-135. doi:10.5555/conu.2007 .25.1-2.124

Gillespie, C. F., Phifer, J., Bradley, B., \& Ressler, K. J. (2009). Risk and resilience: Genetic and environmental influences on development of the stress response. Depression and Anxiety, 26(11), 984992. doi:10.1002/da.20605 
Golding, J. M., Siege, J. M., Sorenson, S. B., Burnam, M. A., \& Stein, J. A. (1989). Social support sources following sexual assault. Journal of Community Psychology, 17(1), 92-107. doi:10.1002/15206629(198901)17:1<92::AID-JCOP2290170110>3.0.CO;2-E

Gross, J. J. (2014). Emotion regulation: Conceptual and empirical foundations. In J. J. Gross (Ed.), Handbook of emotion regulation (2nd ed., pp. 3-20). New York: The Guilford Press.

Gross, J. J., \& John, O. P. (2003). Individual differences in two emotion regulation processes: Implications for affect, relationships, and well-being. Journal of Personality and Social Psychology, 85(2), 348-362.

Gunderson, L. H. (2000). Ecological resilience-in theory and application. Annual Review of Ecology and Systematics, 31, 425-439.

Gupta, S., \& Bonanno, G. A. (2010). Trait self-enhancement as a buffer against potentially traumatic events: A prospective study. Psychological Trauma: Theory, Research, Practice, and Policy, 2(2), 83-92. doi:https://doi.org/10.1037/a0018959

Haglund, M., Cooper, N., Southwick, S., \& Charney, D. (2007). 6 keys to resilience for PTSD and everyday stress. Current Psychiatry, 6(4), 23-30.

Hawn, S. E.,Overstreet, C., Stewart, K. E., \& Amstadter, A. B. (2015). Recent advances in the genetics of emotion regulation: A review. Current Opinion in Psychology, 3, 108-116. doi:10.1016/j.copsyc .2014 .12 .014

Helgeson, V. S., \& Lopez, L. (2010). Social support and growth following adversity. In J. W. Reich, A. J. Zautra, \& J. S. Hall (Eds.), Handbook of adult resilience (pp. 309-330). New York: The Guilford Press.

Henje Blom, E., Duncan, L. G., Ho, T. C., Connolly, C. G., LeWinn, K. Z., Chesney, M., . . Y Yang, T. T. (2014). The development of an RdoC-based treatment program for adolescent depression: "Training for Awareness, Resilience, and Action" (TARA). Frontiers in Human Neuroscience, 8, 630. doi:10.3389/fnhum.2014.00630

Hirano, M. (2010). A study of the classification of resilience factors: Development of the bidimensional resilience scale (BRS). The Japanese Journal of Personality, 19(2), 94-106.

Holzel, B. K., Lazar, S. W., Gard, T., Schuman-Olivier, Z., Vago, D. R., \& Ott, U. (2011). How does mindfulness meditation work? Proposing mechanisms of action from a conceptual and neural perspective. Perspectives on Psychological Science, 6(6), 537-559. doi:10.1177/1745691611419671

Horsburgh, M. E., \& Ferguson, A. L. (2012). Salutogenesis: Origins of health and sense of coherence. In V. H. Rice (Ed.), Handbook of stress, coping, and health (2nd ed.). Thousand Oaks, CA: SAGE Publications, Inc.

House, J. S., \& Kahn, R. L. (1985). Measures and concepts of social support. In D. Williams \& S. Cohen (Eds.), Social support and health (pp. 83-108). San Diego, CA: Academic Press.

International Society of Nurses in Genetics. (2016). Genetics/genomics nursing: Scope and standards of practice (2nd ed.). Silver Spring, MD: American Nurses Association.

Ishihara, Y., \& Nakamaru, S. (2007). A review and perspective on "resilience." Bulletin of Hiroshima Bunkyo Women's University, 42, 53-81.

Johnson, D. C., Polusny, M. A., Erbes, C. R., King, D., King, L., Litz, B. T., .. Southwick, S. M. (2011). Development and initial validation of the Response to Stressful Experiences Scale. Military Medicine, 176(2), 161-169.

Kaniasty, K. (2012). Predicting social psychological well-being following trauma: The role of postdisaster social support. Psychological Trauma: Theory, Research, Practice, and Policy, 4(1), 22-33.

Kaniasty, K., \& Norris, F. H. (2009). Distinctions that matter: Received social support, perceived social support, and social embeddedness after disasters. In Y. Neria, S. Galea, \& F. H. Norris (Eds.), Mental health and disasters (pp. 175-200). New York: Cambridge University Press. 
Kim-Cohen, J., \& Gold, A. L. (2009). Measured gene-environment interactions and mechanisms promoting resilient development. Current Directions in Psychological Science, 18(3), 138-142. doi:10.1111/ j.1467- 8721.2009.01624.x

Kim-Cohen, J., \& Turkewitz, R. (2012). Resilience and measured gene-environment interactions. Development and Psychopathology, 24(4), 1297-1306. doi:10.1017/S0954579412000715

Lam, W. W., Bonanno, G. A., Mancini, A. D., Ho, S., Chan, M., Hung, W. K., . . Fielding, R. (2010). Trajectories of psychological distress among Chinese women diagnosed with breast cancer. Psycho-Oncology, 19(10), 1044-1051. doi:10.1002/pon.1658

Lee, H., Gill, J., Barr, T., Yun, S., \& Kim, H. (2017). Primer in Genetics and Genomics, Article 2Advancing Nursing Research with Genomic Approaches. Biological Research for Nursing, 19(2), 229-239. doi:10.1177/1099800416689822

Lemery-Chalfant, K. (2010). Genes and environments: How they work together to promote resilience. In J. W. Reich, A. J. Zautra, \& J. S. Hall (Eds.), Handbook of adult resilience (pp. 55-78). New York: The Guilford Press.

Letzring, T. D., Block, J., \& Funder, D. C. (2005). Ego-control and ego-resiliency: Generalization of self-report scales based on personality descriptions from acquaintances, clinicians, and the self. Journal of Research in Personality, 39(4), 395-422. doi:https://doi.org/10.1016/j.jrp.2004.06.003

Luthar, S. S., Cicchetti, D., \& Becker, B. (2000).The construct of resilience:A critical evaluation and guidelines for future work. Child Development, 71(3), 543-562.

Luthar, S. S., \& Zelazo, L. B. (2003). Research on resilience: An integrative review. In S. S. Luthar (Ed.), Resilience and vulnerability: Adaptation in the context of childhood adversities (pp. 510-550). Cambridge, UK: Cambridge University Press.

Mancini, A. D., \& Bonanno, G. A. (2010). Resilience to potential trauma: Toward a lifespan approach. In J. W. Reich, A. J. Zautra, \& J. S. Hall (Eds.), Handbook of adult resilience. New York: TheGuilford Press.

Masten, A. S., Monn, A. R., \& Supkoff, L. M. (2011). Resilience in children and adolescents. In S. M. Southwick, B. T. Litz, D. Charney, \& M. J. Friedman (Eds.), Resilience and mental health: Challenges across the lifespan (pp. 103-119). New York: Cambridge University Press.

Masten, A. S., \& Narayan, A. J. (2012). Child development in the context of disaster, war, and terrorism: Pathways of risk and resilience. Annual Review of Psychology, 63, 227-257. doi:10.1146/annurevpsych-120710-100356

McLaughlin, K. A., Mennin, D. S., \& Farach, F. J. (2007). The contributory role of worry in emotion generation and dysregulation in generalized anxiety disorder. Behaviour Research and Therapy, 45(8), 1735-1752. doi:10.1016/j.brat.2006.12.004

Moffitt, T. E., Caspi, A., \& Rutter, M. (2006). Measured gene-environment interactions in psychopathology: Concepts, research strategies, and implications for research, intervention, and public understanding of genetics. Perspectives on Psychological Science, 1(1), 5-27. doi:10.1111/j.1745-6916 .2006.00002.x

NHK, Nippon Hoso Kyokai. (2014). How to foster "the unbreakable mind." Retrieved from http://www.nhk.or.jp/gendai/articles/3486/1.html

Nilsson, K. W., Leppert, J., Simonsson, B., \& Starrin, B. (2010). Sense of coherence and psychological well-being: Improvement with age. Journal of Epidemiology and Community Health, 64(4), 347-352. doi:10.1136/jech.2008.081174

Nishizono, M. (2007). Horobi tsutsu aru zinrui no huan to seishin igaku. Seishinkeishi, 109(76-80). 
Norris, F. H., Friedman, M. J., Watson, P. J., Byrne, C. M., Diaz, E., \& Kaniasty, K. (2002). 60,000 disaster victims speak: Part I. An empirical review of the empirical literature, 1981-2001. Psychiatry, 65(3), 207-239.

Norris, F. H., Tracy, M., \& Galea, S. (2009). Looking for resilience: Understanding the longitudinal trajectories of responses to stress. Social Science and Medicine, 68(12), 2190-2198. doi:10.1016/ j.socscimed.2009.03.043

Olsson, C. A., Bond, L., Burns, J. M., Vella-Brodrick, D. A., \& Sawyer, S. M. (2003). Adolescent resilience: A concept analysis. Journal of Adolescence, 26(1), 1-11.

Ong, A. D., Bergeman, C. S., \& Boker, S. M. (2009). Resilience comes of age: Defining features in later adulthood. Journal of Personality, 77(6), 1777-1804. doi:10.1111/j.1467-6494.2009.00600.x

Ong, A. D., Fuller-Rowell, T. E., \& Bonanno, G. A. (2010). Prospective predictors of positive emotions following spousal loss. Psychology and Aging, 25(3), 653-660. doi:10.1037/a0018870

Orcutt, H. K., Bonanno, G. A., Hannan, S. M., \& Miron, L. R. (2014). Prospective trajectories of posttraumatic stress in college women following a campus mass shooting. Journal of Traumatic Stress, 27(3), 249-256. doi:10.1002/jts.21914

Pangallo, A., Zibarras, L., Lewis, R., \& Flaxman, P. (2015). Resilience through the lens of interactionism: A systematic review. Psychological Assessment, 27(1), 1-20. doi:10.1037/pas0000024

Perry, R.W. (1983). Environmental hazards and psychopathology: Linking natural disasters withmental health. EnvironmentalManagement, 7(6), 543-551. doi:10.1007/bf01871354

Plomin, R., Defries, J. C., Knopik, V. S., \& Neiderhiser, J. M. (2013). Behavioural genetics (6th ed.). New York: Worth Publishers.

Pluess, M. (2015). Individual differences in environmental sensitivity. Child Development Perspectives, 9(3), 138-143. doi:10.1111/cdep.12120

Reich, J. W., Zautra, A. J., \& Hall, J. S. (2010). Handbook of adult resilience. New York: The Guilford Press.

Rutten, B. P., Hammels, C., Geschwind, N., Menne-Lothmann, C., Pishva, E., Schruers, K., . . Wichers, M. (2013). Resilience in mental health: Linking psychological and neurobiological perspectives. Acta Psychiatrica Scandinavica, 128(1), 3-20. doi:10.1111/acps.12095

Rutter, M. (1987). Psychosocial resilience and protective mechanisms. American Journal of Orthopsychiatry, 57(3), 316-331.

Rutter, M. (2012). Resilience as a dynamic concept. Development and Psychopathology, 24, 335-344. doi:10.1017/S0954579412000028

Sheppes, G., \& Gross, J. J. (2013). Emotion regulation effectiveness: What works when. In I. B. Weiner (Ed.), Handbook of Psychology (2nd ed., pp. 391-405). Hoboken, NJ: John Wiley \& Songs, Inc.

Simmons, A., \& Yoder, L. (2013). Military resilience: A concept analysis. Nursing Forum, 48(1), 17-25. doi:10.1111/nuf.12007

Simpson, D. P. (1959). Cassell's new Latin dictionary: Latin-English, English-Latin. NewYork: Funk \& Wagnalls.

Simpson, J. A., \& Weiner, E. S. C. (1989). The Oxford English dictionary (2nd ed. Vol. XIII). New York: Oxford University Press.

Southwick, S. M., Bonanno, G. A., Masten, A. S., Panter-Brick, C., \& Yehuda, R. (2014). Resilience definitions, theory, and challenges: Interdisciplinary perspectives. European Journal of Psychotraumatology, 5. doi:10.3402/ejpt.v5.25338

Southwick, S. M., \& Charney, D. S. (2012a). Resilience: The science of mastering life's greatest challenges. New York: Cambridge University Press. 
Southwick, S. M., \& Charney, D. S. (2012b). The science of resilience: Implications for the prevention and treatment of depression. Science, 338(6103), 79-82. doi:10.1126/science.1222942

Southwick, S. M., \& Charney, D. S. (2012c). Social support: Learning the tap code. In S. M. Southwick \& D. S. Charney (Eds.), Resilience: The science of mastering life's greatest challenges (pp. 100-114). New York: Cambridge University Press.

Southwick, S. M., Litz, B. T., Charney, D., \& Friedman, M. J. (2011). Resilience and mental health: Challenges across the lifespan. Cambridge: Cambridge University Press.

Stretch, R. H. (1986). Incidence and etiology of post-traumatic stress disorder among active duty army personnel. Journal of Applied Social Psychology, 16(6), 464-481. doi:10.1111/j.1559-1816.1986 .tb01153.x

Substance Abuse and Mental Health Services Administration. (2014). SAMHSA's concept of trauma and guidance for traumainformed approach. Retrieved from http://store.samhsa.gov/shin/content/SMA14-4884/SMA14-4884.pdf

Taylor, Z. E., Sulik, M. J., Eisenberg, N., Spinrad, T. L., Silva, K. M., Lemery-Chalfant, K., . . . Verrelli, B. C. (2014). Development of egoresiliency: Relations to observed parenting and polymorphisms in the serotonin transporter gene during early childhood. Social Development, 23(3), 433-450. doi:10.1111/sode.12041

Thompson, R. W., Arnkoff, D. B., \& Glass, C. R. (2011). Conceptualizing mindfulness and acceptance as components of psychological resilience to trauma. Trauma Violence Abuse, 12(4), 220-235. doi:10.1177/1524838011416375

Tugade, M. M., \& Fredrickson, B. L. (2004). Resilient individuals use positive emotions to bounce back from negative emotional experiences. Journal of Personality and Social Psychology, 86(2), 320333. doi:10.1037/0022-3514.86.2.320

Tusaie, K., \& Dyer, J. (2004). Resilience:A historical reviewof the construct. Holistic Nursing Practice, 18(1), 3-8; quiz 9-10.

Vaillant, G. E. (2003). Mental health. American Journal of Psychiatry, 160(8), 1373-1384. doi:10.1176/ appi.ajp.160.8.1373

van Ijzendoorn, M. H., Belsky, J., \& Bakermans-Kranenburg, M. J. (2012). Serotonin transporter genotype 5HTTLPR as a marker of differential susceptibility? A meta-analysis of child and adolescent gene-by-environment studies. Translational Psychiatry, 2, e147. doi:10.1038/tp.2012.73

Veit, C. T., \& Ware, J. E., Jr. (1983). The structure of psychological distress and well-being in general populations. Journal of Consulting and Clinical Psychology, 51(5), 730-742.

Waaktaar, T., \& Torgersen, S. (2012). Genetic and environmental causes of variation in trait resilience in young people. Behavior Genetics, 42(3), 366-377. doi:10.1007/s10519-011-9519-5

Wagnild, G. M., \& Young, H. M. (1993). Development and psychometric evaluation of the Resilience Scale. Journal of Nursing Measurement, 1(2), 165-178.

Walker, L. O., \& Avant, K. C. (2011). Strategies for theory construction in nursing (5th ed.). Norwalk, CT: Appleton, Lange.

Weinberg, A., Venables, N. C., Proudfit, G. H., \& Patrick, C. J. (2015). Heritability of the neural response to emotional pictures: Evidence from ERPs in an adult twin sample. Social Cognitive and Affective Neuroscience, 10(3), 424-434. doi:10.1093/scan/nsu059

Wermter, A. K., Laucht, M., Schimmelmann, B. G., Banaschewski, T., Sonuga-Barke, E. J., Rietschel, M., \& Becker, K. (2010). From nature versus nurture, via nature and nurture, to gene $\times$ environment interaction in mental disorders. European Child and Adolescent Psychiatry, 19(3), 199-210. doi:10.1007/s00787-009-0082-z 
Werner, E. E. (1994). Overcoming the odds. Journal of Developmental and Behavioral Pediatrics, 15(2), 131-136.

Werner, E. E. (2013). What can we learn about resilience from large-scale longitudinal studies? In S. Goldstein \& R. B. Brooks (Eds.), Handbook of resilience in children (2nd ed., pp. 87-102). New York: Springer Science.

Windle, G. (2011). What is resilience? A review and concept analysis. Reviews in Clinical Gerontology, 21(2), 152-169. doi:10.1017/S0959259810000420

Windle, G., Markland, D. A., \&Woods, R. T. (2008). Examination of a theoretical model of psychological resilience in older age. Aging \& Mental Health, 12(3), 285-292. doi:10.1080/13607860802120763

World Health Organization. (1948). Constitution of the world health organization. Retrieved from http://apps.who.int/gb/bd/PDF/bd47/EN/constitution-en.pdf?ua=1

Wu, G., Feder, A., Cohen, H., Kim, J. J., Calderon, S., Charney, D. S., \& Mathe, A. A. (2013). Understanding resilience. Frontiers in Behavioral Neuroscience, 7, 10. doi:10.3389/fnbeh.2013.00010

Yagi, G., Den, R., \& Watanabe, K. (2007). A protective and restitutive system, and resilience in mental disease. Brain Science and Mental Disorders, 18(2), 135-142.

Yehuda, R. (2004). Risk and resilience in posttraumatic stress disorder. Journal of Clinical Psychiatry, 65 Suppl 1, 29-36.

Yehuda, R., Flory, J. D., Southwick, S., \& Charney, D. S. (2006). Developing an agenda for translational studies of resilience and vulnerability following trauma exposure. Annals of the New York Academy of Sciences, 1071, 379-396. doi:10.1196/annals.1364.028

Zauszniewski, J. A., Bekhet, A. K., \& Suresky, M. J. (2010). Resilience in family members of persons with serious mental illness. Nursing Clinics of North America, 45(4), 613-626. doi:10.1016/j.cnur .2010 .06 .007 